\title{
THE EFFECTS OF RURAL DOMESTIC SEWAGE RECLAIMED WATER DRIP IRRIGATION ON CHARACTERISTICS OF RHIZOSPHERE SOIL
}

\author{
LU, S. B. ${ }^{1,2}-$ SHANG, Y. Z. ${ }^{1, *}-$ LIANG, P. ${ }^{3}-$ LI $, W{ }^{2}-\mathrm{WU}, \mathrm{X} . \mathrm{H}^{2}$ \\ ${ }^{1}$ State Key Laboratory of Simulation and Regulation of Water Cycle in River Basin \\ China Institute of Water Resources and Hydropower Research,Beijing 100018, China \\ ${ }^{2}$ School of Public Administration, Zhejiang University of Finance and Economics \\ Hang Zhou 310018, China \\ ${ }^{3}$ Key Laboratory of Water Cycle and Related Land Surface Processes, Institute of Geographic \\ Sciences and Natural Resources Research, Chinese Academy of Sciences, Beijing 100101, China \\ e-mail: 38994327@qq.com \\ *Corresponding author \\ e-mail: yzshang@foxmail.com \\ (Received $10^{\text {th }}$ Apr 2017; accepted $11^{\text {th }}$ Aug 2017)
}

\begin{abstract}
With the shortage of water resource being more and more serious day by day, reclaimed water irrigation is an effective approach to solve this problem. In this article, field experiment is conducted to research and analyze the effects of different proportions of rural domestic sewage reclaimed water drip irrigation on characteristics of rhizosphere soil, using groundwater drip irrigation as sample comparison. The results show that: As for soil physical and chemical characteristics, the soluble salt concentration (EC value) of soil solution under reclaimed water drip irrigation is higher than that under groundwater drip irrigation. However, the $\mathrm{pH}$ values of soil solution under both conditions are similar. As for soil nutrients, compared with sample comparison, reclaimed water irrigation increases the amounts of organic matter in soil and available phosphorus in soil layer, but has no effect on the contents of available nitrogen and available $\mathrm{k}$. The higher the concentration of reclaimed water in irrigation water is, the more obvious the effect on soil respiration is. Under the condition of drip irrigation, with proper agronomic measure and irrigation system, the adoption of certain proportion of rural domestic sewage reclaimed water irrigation is an effective way to reduce reclaimed water pollution.
\end{abstract}

Keywords: soil characteristics; EC value; nutrients

\section{Intrduction}

Reclaimed water resource is a kind of recycled water source, which has great potential value. In China, we are short of water source, especially agricultural water source (Yadav et al., 2002; Ramirez et al., 2002; Lu et al., 2016a). In order to relieve the present situation of water shortage, reclaiming rural domestic sewage and using it for agricultural irrigation is an important way to solve the problem of agricultural water shortage. The effects of reclaimed water on soil physical features change according to the soil characteristics and they mainly show in N, P and salinity contents. The contents of other elements in reclaimed water are similar to that of tap water (Smol et al., 2015; Lu et al., 2016b; Cui and Ouyang, 2015). It has been proved that heavy metals and other organic matters in reclaimed water do not pollute soil obviously. Waste water irrigation, which contains lots of nutrients, helps to increase soil fertility. Since there are traces of saline matters in reclaimed sewage, long-term irrational irrigation can affect soil permeability, for example, excessive salinity 
may accumulate at plant roots, which will change soil components and cause soil to harden; some ions in salinity are poisonous, which can cause physical environment changes; the increase of sodium can reduce soil porosity, which decreases soil's capacity to keep nutrient elements ( $\mathrm{Lu}$ et al., 2015; Wiśniewska-Kadżajan et al., 2017).The effects of both fertility and pollution of reclaimed water determine that effects of sewage irrigation on physical and chemical characteristics especially the fertile of soil is a hot research topic in reclaimed water irrigation. However, the complexity of migration and transmission of irrigation water source in soil system makes the effects of reclaimed water on the fertile of soil a much difficult topic.

Drip irrigation is an effective way to reduce the pollution of reclaimed water. Drip irrigation is a modern irrigation method that allows water and fluid fertilizer to drip in small flow, long time, and high frequency to the soil with crops roots, on the basis of water and fertilizer requirement law of the crops (Badruzzaman et al., 2013; Rao et al., 2017). It can save increase production, save water, fertilizer, labor and energy and adopt well to different kinds of landform and soil, which helps to improve utilization efficiency of water and nutrients and reduce agricultural non-point source pollution while ensures high yield and grade (Jennings and Ma, 2008; Lu et al., 2016c; Lu et al., 2017). The severe control irrigation time and amount and soil moisture area in drip irrigation allows it to adjust soil moisture and nutrients according to the physical property, crop root system distribution and crop water consumption. Recycling rural domestic sewage by drip irrigation can improve the utilization efficiency of $\mathrm{N}, \mathrm{P}$ and other nutrients in reclaimed water, save fertilizer and water, improve production and reduce pollutants that might be put into environmental ecosystem. This is significant for relieving water shortage crisis, controlling agricultural non-point source pollution and promoting circular economy development.

Reusing sewage, applying and promoting reclaimed water is an effective way to increase income and reduce expenditure, important support to construct the economic society, an important measure of harmonious development of realizing economic benefits, society benefits and environment benefits (Becerra-Castro et al., 2015; Islam et al., 2015; Lu et al., 2016d; Lu and Shang, 2017). By using reclaimed water, we can save regular water source, keep and replenish groundwater, and relieve the conflict between water supply and demand in countries, which brings remarkable economy benefits. This article researches and compares effects of rural domestic sewage reclaimed water and groundwater drip irrigation on the characteristics of crop rhizosphere soil, with other conditions being the same (Dragović et al., 2014; Lu et al., 2016b). In this article, field experiment is conducted, and "Agricultural surface pollution control integrated demonstration in the south to North Water Diversion Project", in the southern mountain area, Maojian district, Shiyan city, Hubei province, is used as testing area. By measuring related indexes of harvest soil, it shows that recycling rural domestic sewage by drip irrigation can improve the utilization efficiency of $\mathrm{N}, \mathrm{P}$ and other nutrients in reclaimed water, save fertilizer and water, improve production and reduce pollutants that may be put to environmental ecosystem. It is significant for relieving water shortage crisis, controlling agricultural non-point source pollution and promoting circular economy development. With other conditions same, by comparing the $\mathrm{pH}$ value and $\mathrm{EC}$ value of rural domestic sewage reclaimed water irrigation (Frantz et al., 2012), this experiment analyzes the effects of nutrients contents in soil on soil respiration, and researches and compares the effects of rural domestic sewage reclaimed water and groundwater drip irrigation on characteristics of crop rhizosphere soil. It provides evidences for evaluation of reclaimed water irrigation effects on soil environment and making secure control method. 


\section{Material and method}

\section{Experimental field situation}

The experimental area is "Agricultural surface pollution control integrated demonstration in the south to North Water Diversion Project", which is established by Institute of Geographical Sciences and Natural Resource Research, Chinese Academy of Sciences and The Policy and Technology Research Center of South-north Water Diversion Project Office of the State Council. This area is located in the southern mountain area, Maojian district, Shiyan city, Hubei province in the subtropical monsoon climate area. The four seasons there are distinct, and winter period is long while spring is short. In spring, the temperature rises rapidly. In autumn there are lots of rains. In winter, there are few rains and snows and it is not very cold. The annual amount of solar radiation is $106.6 \mathrm{Kcal} / \mathrm{cm}^{2}$, physiological radiation is $50.4 \mathrm{Kcal} / \mathrm{cm}^{2}$, and average annual sunshine duration is 1925.8 hours. Annual average temperature is $15.3{ }^{\circ} \mathrm{C}$, with extreme low temperature $-14.9{ }^{\circ} \mathrm{Cand}$ extreme high temperature $41{ }^{\circ} \mathrm{C}$. The annual accumulated temperature $\left(\geq 10^{\circ} \mathrm{C}\right)$ is $4936.5^{\circ} \mathrm{C}$. There are 246 frost-free days a year. Multi-year average precipitation is $855 \mathrm{~mm}$ and the precipitations in different year are very different. The precipitation of flood season (from May, $1^{\text {st }}$ to Dec. $20^{\text {th }}$ ) takes up about 58\%-62\% of the whole year, with features of great intensity, short duration and limited infiltration capacity, which can easily scour and erode soil surface. The experimental soil in research is yellow-brown soil and the volume weight of it is $1.56-1.71 \mathrm{~g} / \mathrm{cm}^{3}$.

The reclaimed water used in test station is from the village, in Maojian southern mountain area, Shiyan city, Hubei Province, which is secondary treated reclaimed water. The water quality is stable and the water is just get when used.

\section{Experimental arrangement}

The experiment is conducted from May to September, 2011, the growing season of spinach. The cultivation method of spinach is ridge planting: ridge shoulder width: $40 \mathrm{~cm}$; center space of two ridges: $100 \mathrm{~cm}$; ridge height: $10 \mathrm{~cm}$, two lines of plants per ridge; planting space: $20 \mathrm{~cm}$. They are irrigated by 5 kinds of irrigation water, labeled as following: T1 (full reclaimed water), T2 (joint irrigation of reclaimed water and groundwater with reclaimed water taking up 70\%), T3 (joint irrigation of reclaimed water and groundwater with reclaimed water taking up 50\%), T4 (joint irrigation of reclaimed water and groundwater with reclaimed water taking up 20\%) and $\mathrm{C}$ (full groundwater), as shown in Table 1. There are three small areas for each treatment, with 3 ridges of $4 \mathrm{~m}$ long for each small area, that is $4 \mathrm{~m} \times 3 \mathrm{~m}$ for each small area. The irrigation method is gravity drip irrigation. Drip tapes are placed at the center of each ridge, the spacing of each dripper is $20 \mathrm{~cm}$, same distance as row spacing, dripper discharge is $0.6 \mathrm{~L} / \mathrm{h}$, and that is to say each plant has a dripper near root to provide water. Each treatment (including three small areas) is provided with water by a barrel (volume: $180 \mathrm{~L}$ ). The barrel is put about $2.0 \mathrm{~m}$ high from ground. In the second small test area of each treatment, install a set of suction gauge. When the suction gauge shows that soil water potential is under $-25 \mathrm{kPa}$, the plant will be irrigated, $5 \mathrm{~mm}$ every time, 7 times during growth period, $35 \mathrm{~mm}$ in total.

Before planting spinach, the field is fertilized with DAP fertilizer, 20kg per mu. During experiment, the area with treatment of reclaimed water irrigation (T1, T2, T3 and T4) will not be fertilized again. But for the area with treatment of full groundwater irrigation (C), 100g urea is dissolved in the water of the irrigation barrel before irrigation, and then the area will be fertilized with it. 


\section{Determination indexes and methods}

At the end of spinach growing season, use soil auger to get soil samples under drippers. The sample depth is $0-30 \mathrm{~cm}$ and $30-60 \mathrm{~cm}$. The samples from the three areas with same treatment are mixed as one soil sample. After being dried naturally and triturated, the soil is sorted by $1 \mathrm{~mm}$ sieve. Take exact $20.0 \mathrm{~g}$ soil, add $100 \mathrm{~mm}$ deionized-distilled water, sufficiently oscillate, shake up and filter, take supernatant liquid, under $25{ }^{\circ} \mathrm{C}$, use "DDS-307 type" conductivity meter to measure EC value and meanwhile use "pHS-2C type" meter to measure EC value. Available nitrogen amount in soil is measured by alkaline hydrolysis diffusion method; Available phosphorus amount is measured by 0.05 mol-L-1 $\mathrm{NaHCO}_{3}$ method; Available k amount is measured by $\mathrm{NH}_{4} \mathrm{OAc}$ extraction and flare photometer method; Organic matter amount is measured by the potassium dichromate method. Soil respiration is measured by soil partitioning respiration of Li-6400-09 Portable Photosynthesis System produced by American company Li-cor. The measuring position is under dripper, and the period is three days during growing season, at the time 11:00-12:00, three times repeatedly.

Besides, Table 2 shows the quality of the following water: experimental reclaimed water, which originates from rural domestic sewage, filtered by multi-layer soil infiltration system, groundwater, domestic sewage and reclaimed water. The effects of multi-layer soil infiltration system on treatment of domestic sewage are not obvious. There are many upper limits of indexes in reclaimed water that exceed the upper limits of country's irrigation standard (Lu et al., 2016b; Khamisi et al., 2013; Furumai, 2008). Under reclaimed irrigation, soil-plant system will digest and absorb pollutants in reclaimed water. Under the condition of drip irrigation, if the water volume of a single time is less, the leaching loss of pollutants will be less. With effective coordination of reclaimed water quality and irrigation volume, we can ensure the high production of crops and prevent pollutants from leaching into water body.

Table 1. Treatments of reclaimed water drip irrigation with rural domestic sewage

\begin{tabular}{c|c|c}
\hline No. & Treatment & Irrigation water quality \\
\hline 1 & $\mathrm{~T} 1$ & Full reclaimed water \\
2 & $\mathrm{~T} 2$ & $70 \%$ reclaimed water \\
3 & $\mathrm{~T} 3$ & $50 \%$ reclaimed water \\
4 & $\mathrm{~T} 4$ & $20 \%$ reclaimed water \\
5 & $\mathrm{C}$ & Full groundwater \\
\hline
\end{tabular}

Table 2. Test methods and items of water quality and its comparison with country's irrigation standard

\begin{tabular}{|c|c|c|c|c|c|}
\hline Items & Groundwater & $\begin{array}{c}\text { Domestic } \\
\text { sewage }\end{array}$ & $\begin{array}{c}\text { Reclaimed } \\
\text { water }\end{array}$ & Analysis method & $\begin{array}{c}\text { Irrigation water quality } \\
\text { Standard } \\
\text { (GB5084-2005)-vegetable }\end{array}$ \\
\hline $\mathrm{COD}_{\mathrm{Cr}}\left(\mathrm{mg} \cdot \mathrm{L}^{-1}\right)$ & $3.21 \sim 5.83$ & $450 \sim 730$ & $68 \sim 112$ & dichromate method & 100 \\
\hline $\mathrm{NH}_{3}-\mathrm{N}\left(\mathrm{mg} \cdot \mathrm{L}^{-}\right)$ & $0.08 \sim 0.17$ & 73 108 & $14 \sim 29$ & $\begin{array}{l}\text { Nessler 's reagent } \\
\text { colorimetry }\end{array}$ & - \\
\hline turbidity (NTU) & $0.4 \sim 2$ & $20 \sim 113$ & 21 98 & turbidity meter & - \\
\hline $\mathrm{SS}\left(\mathrm{mg} \cdot \mathrm{L}^{-1}\right)$ & $2 \sim 10$ & $60 \sim 190$ & $30 \sim 60$ & gravimetric methods & 60 \\
\hline Temperature $/{ }^{\circ} \mathrm{C}$ & $10 \sim 20$ & $14 \sim 38$ & $14 \sim 38$ & thermometer & - \\
\hline
\end{tabular}




\begin{tabular}{|c|c|c|c|c|c|}
\hline $\mathrm{pH}$ & $7 \sim 8$ & $6 \sim 9$ & $6 \sim 9$ & $\begin{array}{l}\text { glass electrode } \\
\text { method }\end{array}$ & $6 \sim 9$ \\
\hline $\mathrm{BOD}_{5}\left(\mathrm{mg} \cdot \mathrm{L}^{-1}\right)$ & $1.2 \sim 2.33$ & 179 271 & $28 \sim 47$ & $\begin{array}{c}\text { dilution and seeding } \\
\text { method }\end{array}$ & 40 \\
\hline $\mathrm{DO}\left(\mathrm{mg} \cdot \mathrm{L}^{-1}\right)$ & $0.21 \sim 0.14$ & $2.9 \sim 5.7$ & $2.0 \sim 4.8$ & $\begin{array}{l}\text { Portable } \\
\text { Dissolving } \\
\text { Instrument }\end{array}$ & $\geq 0.5$ \\
\hline $\mathrm{TN}\left(\mathrm{mg} \cdot \mathrm{L}^{-1}\right)$ & $0.99 \sim 2.03$ & $53 \sim 79$ & $17 \sim 37$ & $\begin{array}{c}\text { ultraviolet } \\
\text { spectrophotometry }\end{array}$ & $\leq 30$ \\
\hline $\mathrm{TP}\left(\mathrm{mg} \cdot \mathrm{L}^{-1}\right)$ & $0.08 \sim 0.22$ & $\begin{array}{l}4.9 \sim 10 . \\
\quad 4\end{array}$ & 4.1 9.3 & $\begin{array}{c}\text { ultraviolet } \\
\text { spectroscopy }\end{array}$ & $\leq 30$ \\
\hline
\end{tabular}

\section{Results}

\section{Effects of rural domestic sewage reclaimed water drip irrigation on pH value and EC value of soil}

Soil $\mathrm{pH}$ value is an index of soil acidity-alkalinity, and it is also an important index of critical value of trace elements in soil. The proper $\mathrm{pH}$ value for soil is 7.5 8.4. It is generally acknowledged that reclaimed water irrigation will not cause the increase of soil pHvalue (Yi et al., 2011; Gaydon et al., 2012). In this research, in 0 30cm deep soil layer, the $\mathrm{pH}$ value decreases gradually with the increasing proportion of reclaimed water in irrigation water. Compared with $\mathrm{C}$ treatment, the reductions of T1-T4 are only $5.4 \%$, $2.3 \%, 1.9 \%$ and $1.5 \%$ respectively (refer to Figure 1). As for $30 \sim 60 \mathrm{~cm}$ deepsoil layer, the difference of soil $\mathrm{pH}$ is not obvious. This indicates that compared with full groundwater irrigation, different proportions of rural domestic sewage reclaimed water drip irrigation does not have great effect on soil $\mathrm{pH}$ value.

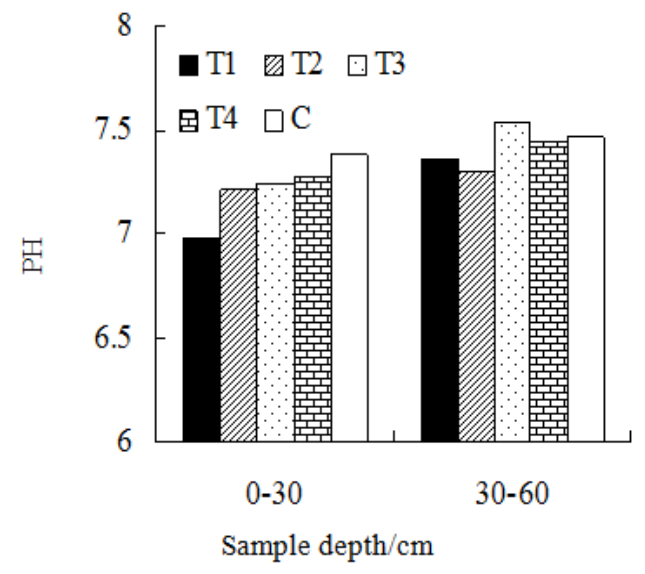

Figure 1. Effects of rural domestic sewage reclaimed water drip irrigation on soil $p H$ value

Soil EC value is an index of soluble salt content in soil solution. High concentration of soluble salt will damage plants and cause the death of plant roots. As shown in Figure 2, rural domestic sewage reclaimed water irrigation has significant effect on soil EC value. Compared with groundwater drip irrigation, the EC values of upper and lower soil layer under T1 treatment and full reclaimed water drip irrigation are higher. However, the soil EC value under $20 \%$ and $50 \%$ reclaimed water drip irrigation increases little, especially 
for the lower soil layer, which shows no obvious difference (Darouich et al., 2012; Mouri et al., 2013). In conclusion, high proportion of reclaimed water drip irrigation significantly increases EC value of upper soil layer.

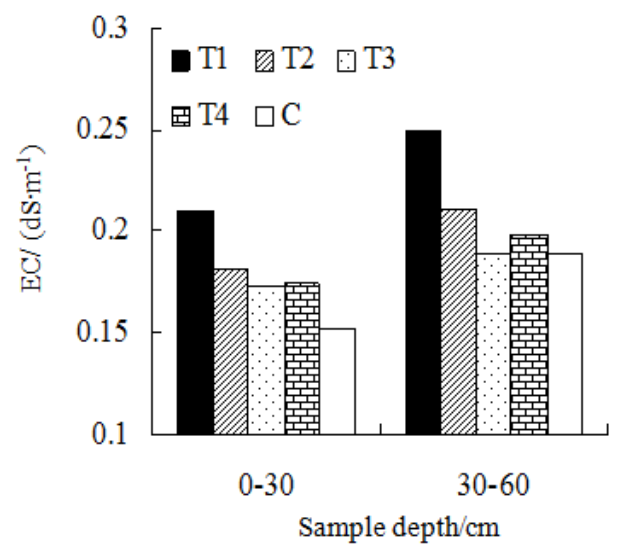

Figure 2. Effects of rural domestic sewage reclaimed water drip irrigation on soil EC value

\section{Effects of rural domestic sewage reclaimed water drip irrigation on soil nutrition content}

Soil can provide everlasting and low-dose available nutrients (Nayak and Prasanna, 2007;). A lot of domestic and overseas researches on soil fertility levels after reclaimed water irrigation are made, and one coincident conclusion is made as following: reclaimed water irrigation can significantly improve soil fertility and long-term irrigation can reduce artificial fertilization (Sidhu et al., 2013; Hooper et al., 2014; Samsó and García, 2013). The potassium amount increases more in reclaimed water irrigation area, which is caused by its absorption and transformation in soil. Soil organic matter content is an important index of assessing soil fertility, which is relevant to various kinds of soil nutrients and has significant effect on soil physical property such as water retention and supply capacity, porosity and aggregate degree, etc (Lu et al., 2016a). As shown in Figure 3, with the increase of reclaimed water proportion in irrigation water, the organic matter amount increases, and the increasing trend is more obvious in upper layer soil. The organic matter contents in soil under full reclaimed water drip irrigation and $70 \%$ reclaimed water drip irrigation are obviously higher than other, which indicates that reclaimed water drip irrigation can increase organic matter contents in soil.

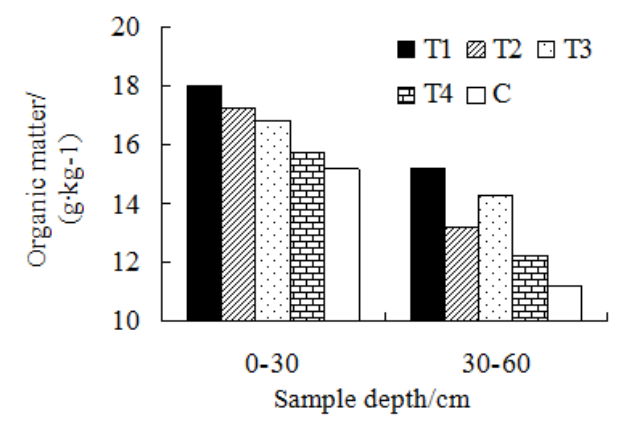

Figure 3. Effects of rural domestic sewage reclaimed 
In upper soil layer of $0 \sim 30 \mathrm{~cm}$ deep, the available nitrogen contents in soil under $\mathrm{T} 1$ (full reclaimed water irrigation) and $\mathrm{C}$ (additional nitrogen) treatment are much higher than others (refer to Figure 4). In 30 60cm deep soil layer, the nitrogen content in soil under T1 treatment is higher, and no obvious difference under other treatments. Generally speaking, except for soil under full reclaimed water irrigation, the increase of available nitrogen is not obvious for soil under different proportion of reclaimed water drip irrigation. The reason may be that reclaimed water drip irrigation increases the organic matter contents which increases the growth of plant and then promotes the consumption of nitrogen in soil, so that there is no obvious difference of nitrogen under $\mathrm{T} 2, \mathrm{~T} 3$ and $\mathrm{T} 4$ treatments.

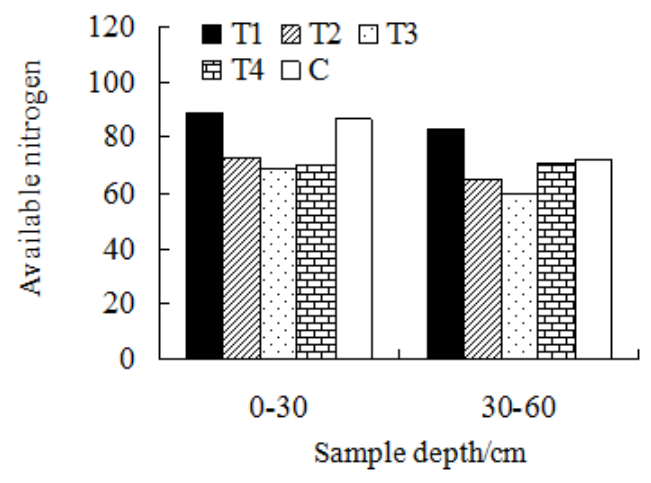

Figure 4. Effects of rural domestic sewage

Different proportions of reclaimed water drip irrigation have great effect on available phosphorus contents in spinach rhizosphere soil (refer to Figure 5). In 0 30cm deep soil layer, except for soil under T4 treatment (20\% reclaimed water drip irrigation), the available phosphorus contents in soil under T1, T2, T3 treatments are higher than soil under full underground water drip irrigation. In lower soil layer $(30 \sim 60 \mathrm{~cm})$, available phosphorus contents in soil under T1 and T2 treatments are obviously higher than other treatments. There is no obvious difference between other three kinds of treatments. It indicates that high proportion of reclaimed water drip irrigation can greatly increase available phosphorus content in soil.

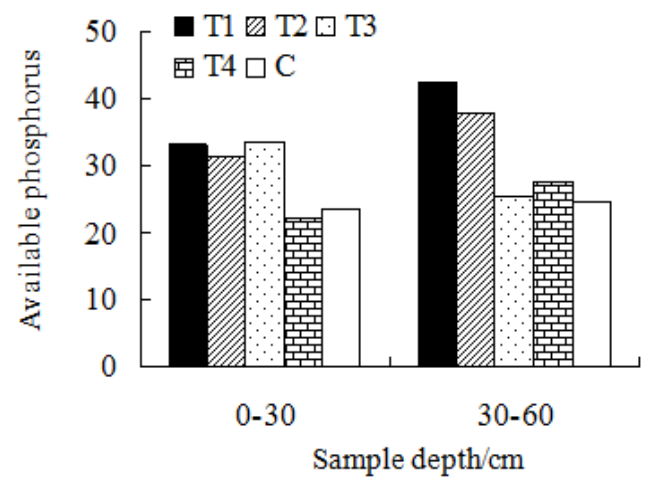

Figure 5. Effects of rural domestic sewage reclaimed 
As shown in Figure 6, different proportions of reclaimed water drip irrigation have little effect on available $\mathrm{K}$ content in spinach rhizosphere soil. In $0 \sim 30 \mathrm{~cm}$ deep soil layer, with increase of reclaimed water proportion in irrigation water, the available $\mathrm{K}$ content increases gradually, but the difference is not obvious. In lower soil layer $(30 \sim 60 \mathrm{~cm})$, available K contents in soil with full reclaimed water drip irrigation and $70 \%$ reclaimed water drip irrigation are a little higher than full groundwater drip irrigation. There is no obvious difference among other treatments. Generally speaking, rural domestic sewage reclaimed water drip irrigation has little effect on available $\mathrm{K}$ contents in spinach rhizosphere soil. Bajaj and Singh (2015) considers that reclaimed water drip irrigation can provide nutrients for soil, especial potassium fertilizer, so that we can use 24. 5 97. $8 \mathrm{~kg} / \mathrm{hm}^{2}$ less potassium fertilizer than regular irrigation.

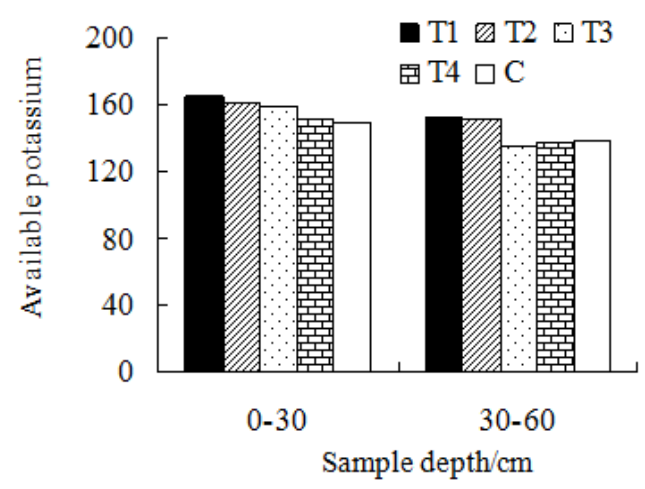

Figure 6. Effects of rural domestic sewage reclaimed

From the experimental results, under combined effects of internal and external factors, such as physiological activity of plant root cells, maintenance and management practice, change of climate conditions, etc., if irrigating spinach field by slightly alkaline $(\mathrm{pH}>7)$ reclaimed water, the $\mathrm{pH}$ value of the soil will decrease a little, which means the acid is enhanced. The enhanced soil acid will accelerate the humification process of organic matter, which will enhance soil acid and accelerate the liberalization and ionization process of N, P, and Ketc. This makes them in an existential state that is easy to run off with water, and digest and use by plant. So that elements, such as N, P, K, etc., will not accumulate in soil and neither will growth failure or large-area death happens because of the accumulation of $\mathrm{N}, \mathrm{P}, \mathrm{K}$, etc.

\section{Effects of rural domestic sewage reclaimed water drip irrigation on soil respiration}

Soil respiration refers to all the metabolic activities in soil that can produce carbon dioxide (Yang et al., 2015; Rezgui et al., 2016). It mainly includes respiration of plant roots (part of autotrophic respiration), heterotrophic respiration of soil microbes and animal, and it is an import index that reflects the soil fertility characteristics. Figure 7 shows effects of different proportion of reclaimed water drip irrigation on soil respiration. As shown in Figure 7, different proportions of reclaimed water drip irrigation can all promote soil respiration. The larger the proportion is, the more obvious the promotion and the faster the respiratory rate is. This is because reclaimed water drip irrigation does not only increase nutrients in soil such as organic matter, but also increases the amount of various kinds of microbes in soil. Microbes in soil use organic matters as energy 
substance, decompose them step by step and release them in form of $\mathrm{CO}_{2}$ and mineral nutrients, which provides plants with available nutrients.

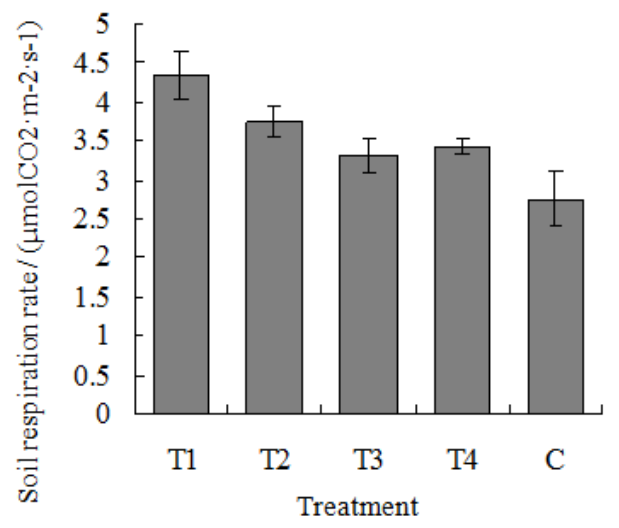

Figure 7. Effects of rural domestic sewage reclaimed water

\section{Conclusion}

Rural domestic sewage reclaimed water drip irrigation will not cause obvious or anomalous change of soil $\mathrm{pH}$ value, but high proportion of reclaimed water drip irrigation can increase EC value of upper soil layer. Relatively speaking, rural domestic sewage reclaimed water drip irrigation has little effect on available nitrogen and available $\mathrm{K}$, but has significant effects on organic matter andavailable phosphorus. Besides, there is no anomalous change in plant growth because of sewage pollutants accumulation in soil; it indicates that reclaimed water, used as irrigation water, can improve soil fertilizer to some extent, and in the aspect of heavy metal, reclaimed water irrigation is safe. Reclaimed water drip irrigation can promote soil respiration. The larger the proportion of reclaimed water is, the faster the respiratory rate is.

Therefore, under the condition of drip irrigation, with proper agronomic measure and irrigation system, certain proportion of rural domestic sewage reclaimed water can be adopted to irrigate crops. The results also show that, to some extent, the pollutants in reclaimed water still accumulate in soil, and they have effect on plant growth. As for the effect degree and period, we need to make long-term experiments and do further observation and research.

Acknowledgments. This research was supported by the Research Centre of Government Regulation and Public Policy, the National Natural Science Foundation of China (Grant No.:51379219,51579248), Zhejiang province Funds for Distinguished Young Scientists (Grant No.: LR15E090002) and the Open Research Fund of State Key Laboratory of Simulation and Regulation of Water Cycle in River Basin (China Institute of Water Resources and Hydropower Research) (Grant No.: IWHR-SKL-201619).

Conflict of Interests. The authors declared that they have no conflict of interests to this work.

\section{REFERENCES}

[1] Badruzzaman, M., Oppenheimer, J.A., Jacangelo, J.G. (2013): Impact of environmental conditions on the suitability of microconstituents as markers for determining nutrient loading from reclaimed water. - Water Research 47(16):6198-6210. 
[2] Bajaj, S., Singh, D.K. (2015): Biodegradation of persistent organic pollutants in soil, water and pristine sites by cold-adapted microorganisms: Mini review. - International Biodeterioration \& Biodegradation 100(5):98-105.

[3] Becerra-Castro, C., Lopes, A.R., Vaz-Moreira, I., Silva, E.F., Manaia, C.M., Nunes, O.C. (2015): Wastewater reuse in irrigation: A microbiological perspective on implications in soil fertility and human and environmental health. - Environment International 75(2): 117-135.

[4] Cui, L.H., Ouyang, Y. (2015): Removal of nutrients from septic tank effluent with baffle subsurface-flow constructed wetlands. - Journal of Environmental Management 153(4): 33-39.

[5] Darouich, H., Gonçalves, J.M., Muga, A., Pereira, L.S. (2012): Water saving vs. farm economics in cotton surface irrigation: An application of multicriteria analysis. Agricultural Water Management 115(12): 223-231.

[6] Dragović, R., Gajić, B., Dragović, D. (2014): Assessment of the impact of geographical factors on the spatial distribution of heavy metals in soils around the steel production facility in Smederevo (Serbia). - Journal of Cleaner Production 84(12): 550-562.

[7] Frantz, A., Pottier, M.A., Karimi, B., Corbel, H., Aubry, E., Haussy, C., Gasparini, J., Castrec-Rouelle, M. (2012): Contrasting levels of heavy metals in the feathers of urban pigeons from close habitats suggest limited movements at a restricted scale. - Environmental Pollution 168(9): 23-28.

[8] Furumai, H. (2008): Rainwater and reclaimed wastewater for sustainable urban water use. - Physics and Chemistry of the Earth, Parts A/B/C 33(5):340-346.

[9] Gaydon, D. S., Meinke, H., Rodriguez, D. (2012): The best farm-level irrigation strategy changes seasonally with fluctuating water availability. - Agricultural Water Management 10(1):33-42.

[10] Hooper, T., Cooper, P., Hunt, A., Austen, M. (2014): A methodology for the assessment of local-scale changes in marine environmental benefits and its application. - Ecosystem Services 8(6): 65-74.

[11] Islam, M.N., Jung, H.Y., Park, J.H. (2015): Subcritical water treatment of explosive and heavy metals co-contaminated soil: Removal of the explosive, and immobilization and risk assessment of heavy metals. - Journal of Environmental Management 163(12): 262-269.

[12] Jennings, A.A., Ma, J. (2008): A model to evaluate a soil's bulk solid phase resistance to extraction analysis. - Environmental Modelling \& Software 23(5):563-568.

[13] Khamisi, S.A.A., Prathapar, S.A., Ahmed, M. (2013): Conjunctive use of reclaimed water and groundwater in crop rotations. - Agricultural Water Management 116(1):228-234.

[14] Lu, S.B., Pei, L., Bai, X. (2015): Study on method of domestic wastewater treatment through new-type multi-layer artificial wetland. - International Journal of Hydrogen Energy 40(34):11207-11214.

[15] Lu, S.B., Wang, J.H., Pei, L. (2016a): Study on the Effects of Irrigation with Reclaimed Water on the Content and Distribution of Heavy Metals in Soil. - Int. J. Environ. Res. Public Health 13: 298-306.

[16] Lu, S.B., Zhang, X.L., Pei, L. (2016b): Influence of Drip Irrigation by Reclaimed Water on the Dynamic Change of the Nitrogen Element in Soil and Tomato Yield and Quality. Journal of Cleaner Production, 139:561-566.

[17] Lu, S.B., Zhang, X.L., Bao, H.J., Skitmore, M. (2016c): Review of social water cycle research in a changing environment. - Renewable and Sustainable Energy Reviews 63:132-140.

[18] Lu, S.B., Zhang, X.L., Wang, J.H., Pei, L. (2016d): Impacts of different media on constructed wetlands for rural household sewage treatment. - Journal of Cleaner Production 127:325-330. 
[19] Lu, S.B., Wang, J.H., Shang, Y.Z., Bao, H.J., Chen, H.X. (2017): Potential Assessment of Optimizing Energy Structure to the City of Carbon Intensity Target. - Applied Energy 194:765-773.

[20] Lu, S.B., Shang, Y. Z. (2017): Economic Benefit Analysis of Joint Operation of Cascaded Reservoirs.- Journal of Cleaner Production, In press, accepted manuscript, Available online 17 August 2017.

[21] Mouri, G., Takizawa, S., Fukushi, K., Oki, T. (2013): Estimation of the effects of chemically-enhanced treatment of urban sewage system based on life-cycle management. - Sustainable Cities and Society 9(12): 23-31.

[22] Nayak, S., Prasanna, N.R. (2007): Soil pH and Its Role In Cyanobacterial Abundance and Diversity in Rice Field Soils. -Applied Ecology \& Environmental Research 5(2):103--113.

[23] Ramirez, F. E., Lucho, C. C., Esacamilla, S. E. et al. (2002): Characteristics, and carbon and nitrogen dynamics in soil irrigated with wastewater for different lengths of time. Bioresource Technology 85(2): 179-187.

[24] Rao, K.V.R., Gangwar, S., Keshri, R., Chourasia, L., Bajpai, A., Soni, K. (2017): Effects of Drip Irrigation System for Enhancing Rice (Oryza Sativa L.) Yield Under System of Rice Intensification Management. - Applied Ecology and Environmental Research 15(4):487-495.

[25] Rezgui F, Gharbi F, Zribi L, Mouillot, F., Ourcival, J.M., Hanchi, B. (2016): Soil Respiration Behaviour in a Mediterranean Aleppo Pine Forest in North Tunisia. Applied Ecology and Environmental Research 14(4):343-356.

[26] Samsó, R., García, J. (2013): Bacteria distribution and dynamics in constructed wetlands based on modelling results. - Science of the Total Environment 461-462(1):430-440.

[27] Sidhu, J. P. S., Ahmed, W., Gernjak, W., Aryal, R., McCarthy, D., Palmer, A., Kolotelo, P., Toze, S. (2013): Sewage pollution in urban stormwater runoff as evident from the widespread presence of multiple microbial and chemical source tracking markers. Science of The Total Environment 463-464(1): 488-496.

[28] Smol, M., Kulczycka, J., Henclik, A., Gorazda, K., Wzorek, Z. (2015): The possible use of sewage sludge ash (SSA) in the construction industry as a way towards a circular economy. - Journal of Cleaner Production 95(15):45-54.

[29] Wang, J.H., Xue, Y.G. (2016): Study on multi-fractal fault diagnosis based on EMD fusion in hydraulic engineering. - Applied Thermal Engineering 103:798-806.

[30] Wiśniewska-Kadżajan, B., Malinowska, E., Misiak, M. (2017): Concentrations of $\mathrm{K}, \mathrm{Mg}$ and $\mathrm{Na}$ and their ionic relations in dactylis glomerata L. Biomass grown in soil with mushroom substrate and mineral fertilisers. - Applied Ecology and Environmental Research 15(3):1269-1278.

[31] Yadav, R.K., Goyal, B., Shrma, R.K., Dubey, S.K., Minhas, P.S. (2002): Post irrigation impact of domestic sevage effluent on composition of soils, crops and groundwater: a case study. - Environment International 28: 481-486.

[32] Yang, W., Song, J.N., Higano, Y., Tang, J. (2015): Exploration and assessment of optimal policy combination for total water pollution control with a dynamic simulation model. - Journal of Cleaner Production 102(9): 342-352.

[33] Yi, L.L., Jiao, W.T., Chen, X.N., Chen, W.P. (2011): An overview of reclaimed water reuse in China. - Journal of Environmental Sciences 23(10):1585-1593. 